\title{
Pengaruh Citra Merek dan Persepsi Kualitas terhadap Keputusan Pembelian Suzuki Satria F150 di Kabupaten Karawang
}

\author{
Faisal Cahya Pramudiya \\ Ajat Sudrajat \\ Manajemen, Universitas Singaperbangsa Karawang, Indonesia \\ Korespondensi penulis: faisal.cahya17080@student.unsika.ac.id
}

\begin{abstract}
The automotive industry is a company engaged in the production of land transportation equipment, including motorcycles. The rapid development of the automotive industry is in line with the human need to move more dynamically. This study aims to determine the role of brand image and product quality perceptions on purchasing decisions for Suzuki Satria F150 motorcycle products in the Karawang Regency. This research is quantitative research that uses a preliminary study and a questionnaire as a data collection instrument. This study uses the formula of unknown populations to determine the number of samples. The sample used in this research is 96 respondents. The primary data that has been collected is processed using SPSS version 25. The results of this study found that brand image and product quality perceptions had a significant effect on purchasing decisions for Suzuki Satria F150 motorcycle products in Karawang Regency.
\end{abstract}

Keywords: Brand image; Buying decision; Motorcycle; Perception of quality.

\begin{abstract}
Abstrak. Industri otomotif adalah perusahaan yang bergerak dalam bidang produksi alat transportasi darat, termasuk motor "bebek" atau kendaraan bermotor roda dua. Perkembangan industri otomotif yang begitu pesat seiring dengan kebutuhan manusia untuk bergerak semakin dinamis. Penelitian ini bertujuan untuk mengetahui peran citra merek dan persepsi kualitas produk terhadap keputusan pembelian produk motor bebek Suzuki Satria F150 di Kabupaten Karawang. Penelitian ini adalah penelitian kuantitatif yang menggunakan studi pendahuluan dan kuesioner sebagai instrumen pengumpulan data. Penelitian ini menggunakan rumus unknow populations untuk menentukan jumlah sampel. Sampel yang digunakan dalam penelitian ini sejumlah 96 orang responden. Data primer yang telah dikumpulkan diolah menggunakan SPSS versi 25. Hasil penelitian ini menemukan bahwa citra merek dan persepsi kualitas produk berpengaruh signifikan terhadap keputusan pembelian produk motor bebek Suzuki Satria F150 di Kabupaten Karawang.
\end{abstract}

Kata Kunci: Citra merek; Keputusan pembelian; Motor bebek; Persepsi kualitas. 
Article Info:

Received: June 8, $2021 \quad$ Accepted: October 7, 2021

Available online: October 20, 2021

DOI: http://dx.doi.org/10.30588/jmp.v11i1.844

\section{LATAR BELAKANG}

Perkembangan teknologi setiap tahunya semakin membaik dan membuat era saat ini terasa lebih dinamis (Lubis, Setiyawan, \& Mukhadiroh, 2019). Hal tersebut menuntut setiap individu mampu bergerak cepat dan tepat dalam melakukan kegiatan. Untuk begerak lebih cepat dan tepat, setiap individu membutuhkan alat pendukung berupa alat tranportasi. Melihat kondisi tersebut, peluang industri otomotif semakin besar setiap tahunnya. Industri otomotif menghasilkan berbagai variasi produk alat transportasi termasuk sepeda motor. Data Daila Research menunjukkan bahwa volume penjualan sepeda motor di Indonesia melonjak pada tahun 2018 dengan pencapaian sebesar 6,9 juta unit motor baru terjual dan membuat Indonesia menjadi negara dengan penjualan sepeda motor terbanyak ketiga di dunia (Holler, Uebernickel, \& Brenner, 2017).

Produsen otomotif yang menghasilkan produk kendaraan roda dua di Indonesia didominasi oleh tiga perusahaan besar, yaitu Honda, Yamaha, dan Suzuki (Otosia.com, 2020). Selain ketiga perusahaan besar tersebut beberapa perusahaan lainnya, seperti Kawasaki, TVS, dan perusahaan lainnya menjual produk sepeda motor dalam skala yang lebih kecil. Persaingan yang begitu ketat di dalam industri otomotif terlihat dari penjualan tahunan berbagai macam varian produk sepeda motor. Salah satu varian tersebut adalah jenis motor "bebek." Data volume penjualan varian produk sepeda motor bebek di Indonesia dari ketiga perusahaan besar tersebut ditunjukkan pada Tabel 1.

Tabel 1. Data Penjualan Motor Bebek di Indonesia Periode Tahun 2017-2019

\begin{tabular}{lcccc}
\hline Merek Motor Bebek & $\mathbf{2 0 1 6}$ & $\mathbf{2 0 1 7}$ & $\mathbf{2 0 1 8}$ & $\mathbf{2 0 1 9}$ \\
\hline Yamaha MX-King series & 68.785 & 53.018 & 26.326 & 60.000 \\
\hline Honda Sonic 150R & 37.695 & 27.375 & 16.216 & 31,200 \\
\hline Suzuki Satria F150 & $\mathbf{3 9 . 4 6 5}$ & $\mathbf{1 2 . 9 3 3}$ & $\mathbf{2 7 . 2 9 8}$ & $\mathbf{2 8 , 0 2 5}$ \\
\hline Honda Supra GTR 150 & 32.820 & 16.605 & 10.063 & 19,600 \\
\hline Sumber: AISI (2020) & & & &
\end{tabular}

Tabel 1 menunjukkan bahwa volume penjualan produk Suzuki Satria F150 mengalami fluktuasi, tetapi pada tahun 2018 hingga 2019 telah mengalami tren kenaikan. Namun, penjualan tersebut masih lebih rendah daripada penjualan Yamaha MX-King dan Honda Sonic 150R. Di sisi lain, penjualan tersebut lebih tinggi daripada penjualan Honda Supra GTR 150. Menurut data Asosiasi Industri Sepeda Motor Indonesia (AISI), pangsa pasar sepeda motor varian bebek masih jauh lebih rendah daripada penjualan sepeda motor varian skuter matic (AISI, 2020). Hal itu disebabkan oleh beberapa faktor, salah satunya adalah pola perilaku konsumen yang menjadi faktor pertimbangan dalam pengambilan keputusan pembelian produk (Lubis et al., 2019).

Faktor lain dalam menghadapi persaingan ketat industri otomotif adalah citra merek dari suatu produk, karena sepeda motor digunakan oleh individu dalam rangka 
memperjelas identitas dirinya agar dipandang baik oleh komunitas atau kalangan tertentu (Azmy, Nauyoman, \& Zakky, 2020). Hal lain yang dipertimbangkan pula oleh konsumen adalah informasi secara tidak langsung mengenai suatu produk (Martín, González-Benito, \& Martos-Partal, 2017). Informasi secara tidak langsung tersebut merupakan persepsi atau pendapat individu mengenai produk berupa komentar terhadap Suzuki Satria F150 yang merangkum beberapa keluhan mengenai produk tersebut (Otosia.com, 2020).

Komentar negatif atau pun keluhan pengguna dapat merusak kesan terhadap suatu produk, sehingga komentar tersebut dapat menimbulkan persepsi yang kurang baik atas kualitas produk (Prochazka et al., 2018). Persepsi kualitas suatu produk berpengaruh terhadap pertimbangan konsumen dalam menggunakan produk tersebut. Penelitian sebelumnya yang dilakukan Foster (2016) mengungkapkan bahwa citra merek berpengaruh signifikan terhadap keputusan pembelian produk air mineral. Penelitian lainnya oleh Lie, Purnomo, dan Sari (2017) mengenai pengaruh persepsi kualitas terhadap keputusan pembelian pada produk keripik Maicih menunjukkan bahwa persepsi kualitas berpengaruh positif terhadap keputusan pembelian produk. Hasil penelitian-penelitian sebelumnya tersebut selaras dengan penelitian mengenai pengaruh citra merek dan persepsi kualitas terhadap keputusan pembelian produk McDonald's, yaitu citra merek dan persepsi kualitas berpengaruh positif terhadap keputusan pembelian oleh konsumen (Robby \& Andjarwati, 2016).

Persaingan industri otomotif menunjukkan tren semakin ketat, khususnya kompetisi pada penjualan motor bebek yang membuat produsen perlu memahami variabelvariabel yang berpengaruh tersebut untuk meningkatkan keefektifan pemasaran produknya. Dari uraian tersebut, penelitian ini bertujuan untuk mengetahui peran citra merek dan persepsi kualitas produk terhadap keputusan pembelian produk motor bebek Suzuki Satria F150 di Kabupaten Karawang.

\section{KAJIAN TEORITIS}

\section{Pemasaran}

Menurut American Marketing Association (AMA), pemasaran adalah perencanaan dan pengendalian operasi pemasaran secara total, termasuk perumusan tujuan pemasaran, kebijakan pemasaran, program pemasaran, dan strategi pemasaran yang ditujukan untuk menciptakan pertukaran guna memenuhi tujuan individual maupun organisasi (Kotler \& Keller, 2016:27). Kotler dan Amstrong (2018:5) menyatakan bahwa pemasaran merupakan proses yang dilakukan perusahaan dengan melibatkan pelanggan dan membangun hubungan pelanggan yang kuat, serta menciptakan nilai bagi pelanggan. Konsep pemasaran yang mencakup semua alat yang tersedia bagi pemasar untuk mengembangkan tindakan secara efisien dan mencapai tujuan penetrasi dan penjualan produk mereka di pasar sasaran disebut bauran pemasaran (Kubicki, 2016:1). Bauran pemasaran terdiri atas kombinasi strategi yang meliputi 7P, yaitu product, price, place, promotion, people, physical evidence, dan process (Hurriyatih, 2019:49). 


\section{Citra Merek}

Menurut Keller, Parameswaran, dan Jacobs (2015:46), citra merek adalah persepsi konsumen tentang suatu merek, seperti yang dicerminkan oleh asosiasi merek yang disimpan dalam memori konsumen. Di sisi lain, Semuel dan Wibisono (2019) menyebutkan bahwa citra merek diartikan sebagai kesan di dalam pemikiran konsumen mengenai personalitas merek dan dikembangkan melalui iklan serta dikonfirmasi langsung oleh pengalaman pribadi. Berdasarkan beberapa pengertian tersebut, citra merek dapat dipahami sebagai pandangan individu yang telah membeli suatu produk dan menilai merek melalui pengalaman menggunakan produk. Menurut Resika, Nazaruddin, dan Handy (2012), citra merek terdiri atas tiga indikator, yaitu citra pembuatan, citra pemakai, dan citra produk. Penelitian oleh Armawati, Saryadi, dan Prabawani (2014) menunjukkan bahwa pengambilan keputusan citra merek merupakan aspek tersendiri bagi konsumen untuk dipertimbangkan, karena semakin positif citra suatu produk, maka konsumen cenderung memutuskan untuk memilih dan menggunakannya, sedangkan Foster (2016) menemukan bahwa citra merek berkontribusi terhadap keputusan pembelian. Dari uraian tersebut, penelitian ini merumuskan hipotesis kesatu (H1) sebagai berikut:

\section{H1: Citra merek berpengaruh signifikan terhadap keputusan pembelian Suzuki Satria F150 di Kabupaten Karawang secara parsial.}

\section{Persepsi Kualitas}

Menurut Pham, Do, dan Phung (2016), persepsi kualitas merupakan temuan pelanggan tentang keunggulan, kredibilitas, dan perbedaan apa pun dari merek suatu produk yang dapat dibandingkan dengan merek produk lain. Santy dan Atika (2020) menyatakan bahwa persepsi kualitas dapat diartikan sebagai penilaian konsumen terhadap keunggulan produk. Menurut Zeithmal, Berry, dan Parasuraman (dalam Armawati et al., 2014), dimensi persepsi kualitas terdiri atas bukti langsung (tangibles), kehandalan (reliability), daya tangkap (Responsiveness), jaminan (assurance), dan empati (empaty). Penelitian Mokhtar, Othman, dan Ariffin (2019) menemukan bahwa persepsi kualitas adalah bagian umum dalam pengambilan keputusan, terutama jika pelanggan perlu memilih produk dari berbagai merek karena persepsi kualitas dari sundut pandang konsumen lain menjadi acuan penilaian. Lie et al., (2017) menemukan bahwa persepsi kualitas berpengaruh positif terhadap keputusan konsumen membeli produk. Dari uraian tersebut, penelitian ini merumuskan hipotesis kedua (H2) sebagai berikut:

\section{H2: Persepsi kualitas berpengaruh signifikan terhadap keputusan pembelian Su- zuki Satria F150 di Kabupaten Karawang secara parsial.}

\section{Keputusan Pembelian}

Menurut Kotler dan Keller, (2016:198), keputusan pembelian merupakan bentuk pemilihan dan minat untuk membeli merek yang paling disukai di antara sejumlah merek yang berbeda. Hutagaol (2019) menyatakan bahwa keputusan pembelian adalah 
tindakan yang dilakukan konsumen untuk melakukan pembelian dengan memilih satu dari beberapa alternatif pilihan produk untuk dibeli. Menurut Kotler dan Keller, (2016:195), enam dimensi dalam keputusan pembelian konsumen, yaitu pilihan produk, pilihan merek, pilihan tempat penyaluran, jumlah pembelian, waktu pembelian, dan metode pembayaran. Robby dan Andjarwati (2016) menemukan bahwa citra merek dan persepsi kualitas berpengaruh positif terhadap keputusan pembelian. Dari uraian tersebut, penelitian ini mengajukan hipotesis ketiga (H3) dengan rumusan sebagai berikut:

\section{H3: Citra merek dan Persepsi Kualitas berpengaruh signifikan terhadap kepu- tusan pembelian Suzuki Satria F150 di Kabupaten Karawang secara simul- tan.}

\section{Model Penelitian}

Penelitian ini dimaksudkan untuk membuktikan pengaruh variabel independen terhadap variabel dependen. Variabel independen dalam penelitian ini terdiri atas dua variabel, yaitu citra merek dan persepsi kualitas, sedangkan variabel dependen dalam penelitian ini adalah keputusan pembelian Suzuki Satria F150. Hubungan antara variabel independen dan dependen dalam penelitian ini digambarkan dalam model penelitian yang ditunjukan pada Gambar 1.

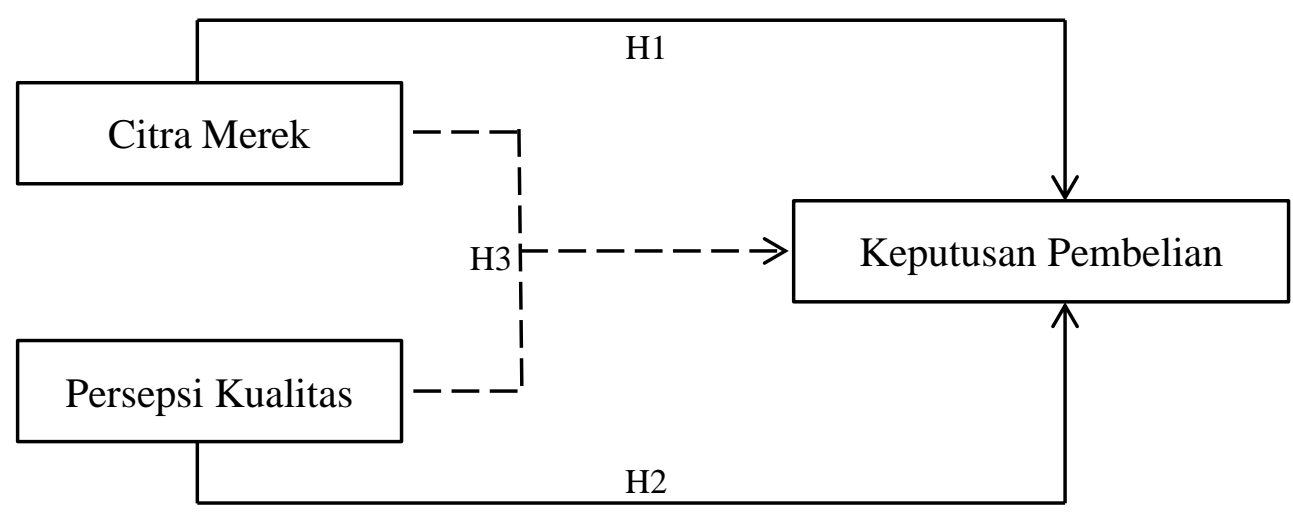

$\stackrel{\text { Keterangan: }}{\longrightarrow}$ : Secara parsial

\section{Gambar 1. Model Penelitian}

\section{METODE PENELITIAN}

Penelitian Ini termasuk jenis penelitian kuantitatif yang digunakan untuk meneliti populasi atau sampel tertentu dengan tujuan menguji hipotesis yang telah dirumuskan (Sugiyono, 2020:14). Populasi yang digunakan dalam penelitian ini adalah pengguna Suzuki Satria F150 di Kabupaten Karawang, Banten. Mengingat populasi pengguna Suzuki Satria F150 tidak diketahui secara pasti jumlahnya, maka teknik pengambilan 
sampel untuk mencari batas minimum sampel dalam penelitian ini menggunakan rumus unknow population (Anwar, 2015) sejumlah 96 responden. Penentuan sampel dalam penelitian ini menggunakan rumusan pada persamaan [1].

Keterangan:

$$
\boldsymbol{n}=\frac{Z_{\alpha_{/ 2} \cdot{ }^{2}}^{2}}{e^{2}}
$$

$\mathrm{n} \quad=$ Jumlah sampel

$\mathrm{Z} \alpha / 2=$ Ukuran tingkat kepercayaan dengan $\alpha=0,05$ yang berarti $\mathrm{Z} 0,05 / 2=\mathrm{Z} 0,025$ dalam tabel ditemukan angka 1,96 (tabel distribusi z)

$\sigma \quad=$ Standar deviasi $(0,5)$

ei $\quad=$ Standart error atau kesalahan yang dapat ditoleransi $(10 \%=0,1)$.

Perhitungan jumlah responden berdasarkan persamaan [1]::

$n=\frac{Z_{\alpha / 2 \cdot \sigma^{2}}^{2}}{e^{2}}$

$n=\left(\frac{(1,96) \cdot(0,5)}{0,1}\right)^{2}$

$n=96,04 \approx 96$ orang responden merupakan jumlah sampel yang ditetapkan dalam penelitian ini.

Tabel 2. Definisi, Indikator, dan Skala Pengukuran Variabel

\begin{tabular}{|c|c|c|c|c|}
\hline No & Variabel & Definisi Operasional & Indiator & $\begin{array}{c}\text { Skala } \\
\text { Pengukuran }\end{array}$ \\
\hline 1 & Citra Merek (X1) & $\begin{array}{l}\text { Cita merek didefinisikan } \\
\text { sebagai kesan dalam pemikiran } \\
\text { konsumen mengenai } \\
\text { personalitas brand dan } \\
\text { biasanya brand image } \\
\text { dikembangkan melalui iklan } \\
\text { dengan tema yang konsisten } \\
\text { dan dikonfirmasi langsung } \\
\text { oleh pengalaman pribadi } \\
\text { konsumen (Semuel \& } \\
\text { Wibisono, 2019). }\end{array}$ & $\begin{array}{l}\text { 1. Citra pembuat } \\
\text { 2. Citra produk } \\
\text { 3. Citra pemakai } \\
\text { (Resika } \text { et al., 2012). }\end{array}$ & $\begin{array}{l}\text { Skala Likert } \\
1-5\end{array}$ \\
\hline 2 & $\begin{array}{l}\text { Persepsi Kualitas } \\
\text { (X2) }\end{array}$ & $\begin{array}{l}\text { Persepsi kualitas produk } \\
\text { diartikan sebagai penilaian } \\
\text { konsumen terhadap } \\
\text { keunggulan produk (Santy \& } \\
\text { Atika, 2020). }\end{array}$ & $\begin{array}{l}\text { 1. Bukti langsung } \\
\text { 2. Keandalan } \\
\text { 3. Daya tangkap } \\
\text { 4. Jaminan } \\
\text { 5. Empati } \\
\text { (Armawati et al., 2014) }\end{array}$ & $\begin{array}{l}\text { Skala Likert } \\
1-5\end{array}$ \\
\hline 3 & $\begin{array}{l}\text { Keputusan } \\
\text { Pembelian (Y) }\end{array}$ & $\begin{array}{l}\text { Keputusan pembelian adalah } \\
\text { tindakan yang dilakukan } \\
\text { konsumen untuk melakukan } \\
\text { pembelian suatu produk atau } \\
\text { dengan kata lain, pengambilan } \\
\text { keputusan konsumen merupa- } \\
\text { kan sebuah proses pemilihan } \\
\text { salah satu dari beberapa } \\
\text { alternatif (Hutagaol, 2019). }\end{array}$ & $\begin{array}{l}\text { 1. Pilihan produk } \\
\text { 2. Pilihan merek } \\
\text { 3. Pilihan tempat } \\
\text { penyalur } \\
\text { 4. Jumlah pembelian } \\
\text { 5. Waktu pembelian } \\
\text { 6. Metode pembayaran } \\
\text { (Kotler \& Keller, } \\
\text { 2015:195). }\end{array}$ & $\begin{array}{l}\text { Skala Likert } \\
1-5\end{array}$ \\
\hline
\end{tabular}

Sumber: Referensi terkait. 
Teknik sampling pada penelitian ini termasuk dalam jenis non-probability sampling dan pengambilannya menggunakan pendekatan incidental sampling. Incidental sampling merupakan teknik pengambilan anggota sampel dari populasi berdasarkan kebetulan (insidental), yaitu siapa pun yang ditemui dan dipilih oleh peneliti dapat digunakan sebagai sampel apabila orang tersebut dinilai tepat menjadi sumber data primer dalam penelitian ini (Sugiyono, 2020:152).

Jenis data dalam penelitian ini adalah data primer, karena data tersebut diperoleh secara langsung dari sumber datanya yaitu responden. Teknik pengumpulan data dalam penelitian ini menggunakan kuesioner untuk data primer dan studi kepustakaan untuk data sekunder pendukung. Studi kepustakaan merupakan teknik untuk mendapatkan sumber referensi dari para ahli melalui literatur yang relevan dan dapat menunjang pengetahuan dan pemahaman tentang citra merek, persepsi kualitas, dan keputusan pembelian, sedangkan kuesioner adalah teknik pengumpulan data menggunakan seperangkat pertanyaan atau pernyataan secara tertulis kepada responden yang ditetapkan sebagai sampel. Definisi operasional variabel, indikator, dan skala pengukuran setiap variabel dalam penelitian ini disajikan pada Tabel 2 .

\section{HASIL DAN PEMBAHASAN}

Data dalam penelitian ini diperoleh dari pengisian kuesioner oleh responden terpilih melalui google form. Setelah data terkumpul sampai dengan jumlah minimum sampel responden sesuai rumus yang digunakan, yaitu 96 responden. Selanjutnya, verifikasi data dilakukan untk menyatakan data benar dan lengkap.

Tabel 3. Karakteristik Responden

\begin{tabular}{llcc}
\hline Karakteristik & \multicolumn{1}{c}{ Kriteria } & Jumlah Responden & Presentase \\
\hline \multirow{2}{*}{ Jenis Kelamin } & Laki-Laki & 78 & $81 \%$ \\
& Perempuan & 18 & $19 \%$ \\
\hline \multirow{3}{*}{ Pendidikan } & Srata dua (S2) & 11 & $12 \%$ \\
& Stara satu (S1) & 25 & $26 \%$ \\
\cline { 2 - 4 } & Ahli Madya (D3) & 29 & $30 \%$ \\
\cline { 2 - 4 } Pekerjaan & Sekolah Menegah Atas (SMA) & 33 & $32 \%$ \\
\hline & ASN (Aparatur Sipil Negara) & 17 & $18 \%$ \\
& Pegawai Swasta & 40 & $42 \%$ \\
& Wirausaha & 34 & $35 \%$ \\
\hline & IRT (Ibu Rumah Tangga) & 5 & $5 \%$ \\
\hline
\end{tabular}

Sumber: Data primer diolah (2020).

\section{Diskripsi Responden}

Berdasarkan hasil pengumpulan data menggunakan kuesioner terhadap 96 orang responden (Tabel 3), mayoritas responden berjenis kelamin laki-laki dengan persentase $81 \%$ atau sebanyak 78 responden dan sisanya yaitu $19 \%$ atau sebanyak 18 responden berjenis kelamin wanita. Mayoritas responden berpendidikan ahli madya (D3) dengan persentase $30 \%$ atau sebanyak 29 responden, tingkat pendidikan responden lainnya adalah strata dua (S2) sebanyak 11 orang responden (11\%), strata satu (S1) sebanyak 26 
responden (27\%), dan sekolah menengah atas (SMA) sebanyak 22 responden $(23 \%)$. Selain itu, mayoritas pekerjaan responden adalah pegawai swasta 40 responden (42\%), Aparatur Sipil Negara (ASN) sebanyak 17 responden (18\%), wirausaha sebanyak 34 responden (35\%), dan ibu rumah tangga (IRT) sebanyak 5 responden $(5 \%)$.

\section{Uji Validitas dan Reliabilitas}

Uji validitas dilakukan untuk mengetahui sah atau valid tidaknya data yang diperoleh dari penyebaran kuesioner. Apabila data tersebut dinyatakan valid, maka pengolahan data dapat dilanjutkan ke tahap pengujian lainnya (Sugiyono, 2020:210). Uji reliabilitas digunakan untuk mengetahui konsintensi responden dalam menjawab kuesioner (Armawati et al., 2014). Uji validitas instumen penelitian ini didasarkan pada variabel dengan ketentuan apabila r-hitung lebih besar dari r-tabel, maka pengujian dinyatakan valid dan jika r-hitung kurang dari dari r-tabel, maka hasilnya dinyatakan tidak valid. Tabel 2 menunjukkan hasil uji validitas instrumen penelitian ini dengan $\mathrm{r}$ tabel 0,300 (Sugiyono, 2020:219). Berdasarkan data pada Tabel 4, hasil uji validitas menunjukkan r-hitung ketiga variabel, yaitu citra merek (X1), persepsi kualitas (X2), dan keputusan pembelian (Y) lebih besar dari 0,300, maka data penelitian ini dapat dinyatakan valid.

Tabel 4. Hasil Uji Validitas

\begin{tabular}{cccccc}
\hline Butir & r-hitung X1 & r-hitung X2 & r-hitung Y & r-tabel & Keterangan \\
\hline 1 & 0,361 & 0,738 & 0,701 & & Valid \\
\hline 2 & 0,675 & 0,734 & 0,756 & & Valid \\
\hline 3 & 0,727 & 0,643 & 0,705 & & Valid \\
\hline 4 & 0,672 & 0,617 & 0,692 & & Valid \\
\hline 5 & 0,441 & 0,533 & 0,539 & 0,300 & Valid \\
\hline 6 & 0,685 & 0,676 & 0,683 & & Valid \\
\hline 7 & 0,705 & 0,765 & 0,466 & & Valid \\
\hline 8 & 0,771 & 0,674 & 0,451 & Valid \\
\hline 9 & 0,452 & 0,370 & 0,612 & & Valid \\
\hline
\end{tabular}

Sumber: Data primer diolah (2020).

Hasil uji reliabilitas terhadap instumen penelitian ini mengikuti ketentuan apabila Cronbach's alpha lebih besar dari 0,6, maka data penelitian dinyatakan reliabel atau sebaliknya (Nurjaya, Affandi, Ilham, Jasmani, \& Sunarsi, 2021). Berdasarkan hasil uji reliabilitas pada Tabel 5, hasil uji r-hitung pada variabel citra merek (X1), persepsi kualitas (X2), dan keputusan pembelian (Y) lebih besar dari 0,6, maka data dalam penelitian ini dapat dinyatakan reliabel.

Tabel 5. Hasil Uji Reliabilitas

\begin{tabular}{lcc}
\hline Variabel & Cronbach's alpha & Keterangan \\
\hline Citra Merek & 0,785 & Reliabel \\
\hline Persepsi Kualitas & 0,891 & Reliabel \\
\hline Keputusan Pembelian & 0,898 & Reliabel \\
\hline Sumber: Data primer diolah (2020). &
\end{tabular}




\section{Analisis Regresi Linear Berganda}

Analisis regresi linear berganda dalam penelitian ini diolah menggunakan software SPSS versi 25. Hasil olah data pada penelitian ini mendapatkan persamaan regresi berganda [2]. Persamaan regresi [2] tersebut menunjukkan bahwa konsanta $(\alpha)$ sebesar -2,729 yang dapat diartikan secara statistika bahwa apabila citra merek (X1) dan persepsi kualitas (X2) tidak ada nilainya atau sama dengan nol, maka keputusan pembelian (Y) akan memiliki nilai sebesar -2,729. Koefisien regresi variabel citra merek (X1) sebesar 0,965 dapat diartikan bahwa apabila variabel citra merek ditingkatkan 1 satuan, maka keputusan pembelian akan meningkat sebesar 0,965 satuan. Jika koefisien tersebut bernilai positif, maka pengaruh citra merek terhadap keputusan pembelian bersifat positif atau meningkat ke arah yang sama. Jadi, peningkatan citra merek berpengaruh signifikan dan positif terhadap keputusan pembelian Suzuki Satria F150 di Kabupaten Karawang. Berdasarkan Tabel 6, hasil analisis dalam penelitian ini menghasilkan persamaan regresi linear berganda pada persamaan [2].

$$
Y=-2,729+0,965 X 1+0,727 X 2
$$

Keterangan:

$\mathrm{Y} \quad=$ Keputusan Pembelian

$\mathrm{X} 1 \quad=$ Citra Merek

$\mathrm{X} 2=$ Persepsi Kualitas.

Koefisien regresi variabel persepsi kualitas (X2) sebesar 0,727 yang dapat diartikan bahwa apabila variabel persepsi kualitas ditingkatkan 1 satuan, maka keputusan pembelian akan meningkat sebesar 0,727 satuan. Jika koefisien tersebut bernilai positif, maka pengaruh persepsi kualitas produk terhadap keputusan pembelian bersifat positif atau meningkat ke arah yang sama. Jadi, peningkatan persepsi kualitas produk Suzuki Satria F150 berpengaruh signifikan dan positif terhadap keputusan pembelian Suzuki Satria F150 di Kabupaten Karawang.

\section{Uji t (Pengaruh Parsial)}

Hasil uji t dalam penelitian ini menunjukkan bahwa variabel citra merek (X1) berpengaruh signifikan secara parsial terhadap keputusan pembelian (Y) Suzuki Satria F150 di Kabupaten Karawang. Hasil uji t variabel citra merek memperoleh nilai t-hitung sebesar 7,160 dengan nilai t-tabel sebesar 1,980 (7,160 > 1,980) dengan nilai signifikansi sebasar 0,000 atau lebih kecil dari 0,05, dan koefisien regresi mempunyai nilai positif sebesar 0,965 (Tabel 6). Hasil tersebut menunjukkan bahwa H1 dapat diterima, yaitu citra merek berpengaruh signifikan secara parsial dalam mendorong konsumen mengambil keputusan untuk membeli produk Suzuki Satria F150 di Kabupaten Karawang.

Tabel 6. Hasil Analisis Regresi Linear Berganda

\begin{tabular}{lccccc}
\hline \multicolumn{1}{c}{ Model } & $\begin{array}{c}\text { Unstandardized } \\
\text { B }\end{array}$ & $\begin{array}{c}\text { Coefficients } \\
\text { Std. Error }\end{array}$ & $\begin{array}{c}\text { Standardized } \\
\text { Coeffisients Beta }\end{array}$ & t & Sig. \\
\hline Constant $)$ & $-2,729$ & 3,588 & - & $-0,761$ & 0,499 \\
\hline Citra Merek & 0,965 & 0,135 & 0,436 & 7,160 & 0,000 \\
\hline Persepsi Kualitas & 0,727 & 0,081 & 0,547 & 8,893 & 0,000 \\
\hline
\end{tabular}

Sumber: Data primer diolah (2020). 
Hasil uji t pada penelitian ini sejalan dengan penelitian terdahulu yang dilakukan oleh Tarmizi (2014) yang menjelaskan bahwa citra merek berpengaruh terhadap keputusan pembelian. Foster (2016) menunjukkan bahwa citra merek berkontribusi terhadap keputusan pembelian. Penelitian ini menemukan bahwa citra merek berkontribusi, baik secara langsung maupun tidak langsung. Hal tersebut terjadi karena perbedaan metode analisis, obyek, dan tempat penelitian.

Hasil berikutnya menunjukkan bahwa variabel persepsi kualitas (X2) berpengaruh signifikan secara parsial terhadap keputusan pembelian (Y) Suzuki Satria F150 di Kabupaten Karawang. Berdasarkan hasil uji t, variabel persepsi kualitas memperoleh nilai t-hitung sebesar 8,893 dengan nilai t-tabel sebesar 1,980 $(8,893>1,980)$ dengan nilai signifikansi sebasar 0,000 atau lebih kecil dari 0,05 , dan koefisien regresi mempunyai nilai positif sebesar 0,727 , sehingga $\mathrm{H} 2$ dapat diterima. Hasil tersebut membuktikan bahwa persepsi kualitas produk berpengaruh signifikan secara parsial dalam memotivasi konsumen untuk mengambil keputusan pembelian Suzuki Satria F150 di Kabupaten Karawang.

Hasil uji t persepsi kualitas tersebut sejalan dengan penelitian terdahulu oleh Lie et al. (2017) yang menemukan bahwa persepsi kualitas berpengaruh positif terhadap keputusan membeli. Namun, penelitian Lie et al. (2017) berfokus pada pengaruh persipsi kualitas terhadap keputusan, sedangkan dalam penelitian ini terdapat dua variabel, yaitu citra merek dan persepsi kualitas terhadap keputusan pembelian. Hal tersebut terjadi karena focus permasalahan yang terdapat pada obyek penelitian.

\section{Uji F (Pengaruh Simultan)}

Uji F dilakukan untuk mengetahui pengaruh variabel bebas secara serentak atau simultan terhadap varibel terikat, yaitu pengaruh citra merek (X1) dan persepsi kualitas (X2) terhadap keputusan pembelian (Y). Hasil uji $\mathrm{F}$ dalam penelitian ini ditunjukkan pada Tabel 7.

Tabel 7. Hasil Uji F

\begin{tabular}{|c|c|c|c|c|c|}
\hline & Model & Sum of Squares & Mean squere & $\mathbf{F}$ & Sig. \\
\hline & Regression & $12.093,439$ & $6.046,719$ & 187,757 & 0,000 \\
\hline & Residual & $2.995,051$ & 32,205 & & \\
\hline & Total & $15.088,500$ & & & \\
\hline
\end{tabular}

Sumber: Data primer diolah (2020).

Hasil uji $\mathrm{F}$ pada variabel citra merek dan persepsi kualitas terhadap keputusan pembelian memperoleh nilai F-hitung sebesar 187,757 dan F-tabel sebesar 3,09 $(187,757>3,09)$ dengan nilai signifikansi sebesar 0,000 atau lebih kecil dari 0,05 $(0,000<0,05)$, sehingga H3 diterima. Hasil ini membuktikan bahwa citra merek dan persepsi kualitas berpengaruh signifikan secara simultan terhadap keputusan pembelian produk Suzuki Satria F150 di Kabupaten Karawang.

Hasil uji $\mathrm{F}$ dalam penelitian ini selaras dengan penelitian terdahulu oleh Robby dan Andjarwati (2016) yang menemukan bahwa citra merek dan persepsi kualitas berpengaruh positif terhadap keputusan pembelian produk. Namun, penelitian tersebut 
menggunakan dimensi dan teknik sampling yang berbeda. Hal tersebut terjadi karena perbedaan pendekatan penelitian dan bidang penelitian.

\section{Uji Koefisien Determinasi}

Hasil uji koefisien determinasi $\left(\mathrm{R}^{2}\right)$ dalam penelitian ini sebesar 0,802 atau 80,2\% (Tabel 8). Hasil uji koefisien determinasi ini menunjukkan bahwa variabel citra merek dan persepsi kualitas mampu menjelaskan variasi keputusan pembelian produk Suzuki Satria F150 di Kabupaten Karawang sebesar 80,2\%, sedangkan sisanya sebesar 19,8\% dijelaskan oleh variabel lain yang tidak digunakan dalam model penelitian ini. Variabel lain yang dapat mempengaruhi keputusan pembelian konsumen di antaranya adalah budaya, sosial, pribadi, dan psikologi (Astuti \& Febriaty, 2017).

Tabel 8. Uji Koefisien Determinasi

\begin{tabular}{ccccc}
\hline Model & $\mathbf{R}$ & $\begin{array}{c}\text { R- } \\
\text { square }\end{array}$ & $\begin{array}{c}\text { Adjusted } \boldsymbol{R}- \\
\text { square }\end{array}$ & $\begin{array}{c}\text { Std. Error of the } \\
\text { Estimate }\end{array}$ \\
\hline 1 & 0,895 & 0,802 & 0,797 & 5,675 \\
\hline Sumber: Data primer diolah $(2020)$. &
\end{tabular}

\section{KESIMPULAN DAN SARAN}

Berdasarkan analisis dan pembahasan hasil penelitian ini, maka variabel citra merek dan persepsi kualitas berpengaruh signifikan dan positif, baik secara parsial maupun simultan terhadap keputusan pembelian produk Suzuki Satria F150 di Kabupaten Karawang. Model penelitian ini dinilai cukup baik dari hasil uji koefisien determinasi karena mampu menjelaskan variasi dalam keputusan pembelian produk Suzuki Satria F150 di Kabupaten Karawang sebesar 80,2\%. Untuk penelitian selanjutnya, variabel yang dianalisis dapat dikembangkan lebih variatif dan jumlah sampel dapat ditambah atau diperluas.

\section{DAFTAR REFERENSI}

AISI (2020). Association of Indonesia Motorcycle Industry: Statistic Distribution. Asosiasi Industri Sepeda Motor Indonesia, 16 Oktober. Diakses tanggal 17 November 2020 di https://www.aisi.or.id/statistic/.

Anwar, I. (2015). Pengaruh Harga dan Kualitas Produk terhadap Keputusan Pembelian. Jurnal Ilmu dan Riset Manajemen, 4(12), 7-15.

Armawati, I., Saryadi, \& Prabawani, B. (2014). Pengaruh Brand Awareness , Brand Image dan Perceived Quality terhadap Keputusan Pemakaian Jasa pada Maskapai Penerbangan Garuda Indonesia. Jurnal Ilmu Administrasi Bisnis, 3(4), 1-9.

Astuti, R., \& Febriaty, H. (2017). Faktor-Faktor yang Mempengaruhi Keputusan Pembelian Konsumen di Pasar Modern: Studi Kasus pada Indomaret di Kecamatan Medan Denai Kota Medan. Jurnal Riset Sains Manajemen, 1(1), 3542. https://doi.org/10.5281/zenodo.1039299. 
Azmy, A., Nauyoman, D., \& Zakky, M. (2020). The Effect of Brand Image and Perception of Products on the Purchase Decisions of Matic Motorcycle in East Belitung. Jurnal Administrasi Bisnis, 9(1), 31-42. https://doi.org/10.14710/jab.v9i1.25278.

Foster, B. (2016). Impact of Brand Image on Purchasing Decision on Mineral Water Product "Amidis" (Case Study on Bintang Trading Company). American Research Journal of Humanities and Social Sciences, 2, 1-11.

Holler, M., Uebernickel, F., \& Brenner, W. (2017). Defining Archetypes of Ecollaboration for Product Development in the Automotive Industry. Proceedings of the 25th European Conference on Information Systems, ECIS 2017, 114-130.

Hurriyatih, R. (2019). Bauran Pemasaran dan Loyalitas Konsumen (Cetakan 2). Bandung: CV Alfabeta.

Hutagaol, C. D. (2019). Analisis Faktor-faktor yang Mempengaruhi Keputusan Pembelian Konsumen di Pajak USU (PAJUSU) Medan. Marketing, 3-13. http://repository.usu.ac.id/bitstream/123456789/23790/4/Chapter I.pdf.

Keller, K. L., Parameswaran, A. M. G., \& Jacobs, I. (2015). Strategic Brand Management: Building, Measuring, and Managing Brand Equity. New Jersey: Pearson Education.

Kotler, P., \& Amstrong, G. (2018). Principles of Marketing (L. Abelli (ed.); Seventeenth).New Jersey: Pearson Education, Inc.

Kotler, P., \& Keller, K. L. (2015). Manajemen Pemasaran (p. 346). Malang: Penerbit Erlangga.

Kotler, P., \& Keller, K. L. (2016). Marketing Managemen. Global Edition. New Jersey: Pearson Education, Inc.

Kubicki, M. (2016). El Marketing Mix (Titivillus (ed.); r2.1). Madrid: ePublibre.

Lie, T. D., Purnomo, D., \& Sari, D. K. (2017). Pengaruh Persepsi Kualitas terhadap Keputusan Pembelian Konsumen pada Keripik Pedas Maicih. Cakrawala Jurnal Penelitian Sosial, 6(1), 137-158.

Lubis, Z., Setiyawan, H., \& Mukhadiroh, L. (2019). The Effect of Consumer Motivation, Quality Perception, and Consumer Attitude to the Decision of Purchase of Honda Brand Motorcycle in Lamongan district. Jurnal Mantik, 3(January), 31-38.

Mokhtar, R., Othman, Z., \& Ariffin, H. F. (2019). The Effect of Brand Awareness, Brand Image, and Perceived Quality on Customer Behaviour Intention. International Journal of Academic Research in Business and Social Sciences, 8(12), 2023-2035. https://doi.org/10.6007/ijarbss/v8-i12/5375.

Nurjaya, N., Affandi, A., Ilham, D., Jasmani, \& Sunarsi, D. (2021). Pengaruh Kompetensi Sumber Daya Manusia dan Kemampuan Pemanfaatan Teknologi terhadap Kinerja Aparatur Desa pada Kantor Kepala Desa di Kabupaten Gunungkidul, Yogyakarta. Jurnal Ilmiah, Manajemen Sumber Daya Manusia, 4(3), 332-346.

Otosia.com (2020). Honda, Yamaha, Suzuki, dan Kawasaki, Siapa yang Paling Tua? Otomotif Indonesia, 27 April. Diakses tanggal 15 November 2020 di 
https://www.otosia.com/berita/honda-yamaha-suzuki-dan-kawasaki-siapa-yangpaling-tua.html.

Pham, L. T. M., Do, H. N., \& Phung, T. M. (2016). The Effect of Brand Equity and Perceived Value on Customer Revisit Intention: A Study in Quick-Service Restaurants in Vietnam. Acta Oeconomica Pragensia, 24(5), 14-30. https://doi.org/10.18267/j.aop.555.

Prochazka, F., Weber, P., \& Schweiger, W. (2018). Effects of Civility and Reasoning in User Comments on Perceived Journalistic Quality. Journalism Studies, 19(1), 6278. https://doi.org/10.1080/1461670X.2016.1161497.

Resika, Y., Nazaruddin, A., \& Handy, T. (2012). Pengaruh Brand Image terhadap Keputusan Konsumen Membeli Produk Sepeda Motor Honda (Studi Kasus pada Mahasiswa Fakultas Ekonomi Universitas Sriwijaya Inderalaya). Jurnal Ilmiah Manajemen Bisnis dan Terapan, 1(1), 31-40.

Robby, M., \& Andjarwati, A. L. (2016). Pengaruh Citra Merek dan Persepsi Kualitas terhadap Keputusan Pembelian McDonald's. Jurnal Ilmu Manajemen, 4(3), 1-7. https://doi.org/10.22219/jmb.v6i2.5541.

Santy, R. D., \& Atika, S. D. (2020). Purchasing Decisions in Terms of Perceived Quality and Product Knowledge. Proceedings of the International Conference on Business, Economics, Social Science, and Humanities - Economics, Business and Management Track (ICOBEST-EBM 2019), 112, 94-99. https://doi.org/10.2991/aebmr.k.200108.023.

Semuel, H., \& Wibisono, J. (2019). Brand Image, Customer Satisfaction dan Customer Loyalty. 13(1), 27-34. https://doi.org/10.9744/pemasaran.13.1.27.

San-Martín, S., González-Benito, Ó., \& Martos-Partal, M. (2017). To What Extent does Need for Touch Affect Online Perceived Quality? International Journal of Retail \& Distribution Management, 45(9), 950-968.

Sugiyono, S. (2020). Metode Penelitian Kuantitatif, Kualitatif, dan Kombinasi (Mixed Methods). Sutopo (ed.), Edisi Revisi. Bandung: CV Alfabeta.

Tarmizi, A. (2014). Pengaruh Citra Merek terhadap Keputusan Pembelian pada Motor Suzuki Satria FU150. Eksis: Jurnal Ilmiah Ekonomi dan Bisnis, 5(1), 1-13. http://dx.doi.org/10.33087/eksis.v5i1.107. 